University of Puget Sound

Sound Ideas

All Faculty Scholarship

Faculty Scholarship

Winter 1983

\title{
Scottish Prisons under the General Board of Directors, 1840-1861
}

David F. Smith

University of Puget Sound, dfsmith@pugetsound.edu

Follow this and additional works at: http://soundideas.pugetsound.edu/faculty_pubs

\section{Citation}

Smith, David F. 1983. "Scottish Prisons Under the General Board of Directors, 1840-1861." Albion 15(4): 287-312.

This Article is brought to you for free and open access by the Faculty Scholarship at Sound Ideas. It has been accepted for inclusion in All Faculty Scholarship by an authorized administrator of Sound Ideas. For more information, please contact soundideas@pugetsound.edu. 


\section{NACBS}

North American

Conference on

British Studies

Scottish Prisons under the General Board of Directors, 1840-1861

Author(s): David F. Smith

Source: Albion: A Quarterly Journal Concerned with British Studies, Vol. 15, No. 4 (Winter, 1983), pp. 287-312

Published by: The North American Conference on British Studies 


\title{
Scottish Prisons Under the General Board of Directors, 1840-1861*
}

\author{
David F. Smith
}

Despite recent interest in both the administration and conditions of prisons in England during the Victorian Period historians have neglected the study of Scottish prisons. It is the intention of this article to redress this omission by assessing the administration of the Scottish penal system between 1840 and 1861 as it developed under the supervision of the General Board of Directors. This Board was equipped with considerable powers over local prisons by the Prisons Act of 1839, and by the time it was replaced by the Managers of Scottish prisons in 1861, it had overseen the completion of an extensive building program to implement the separate system. ${ }^{1}$ Working in conjunction with county prison Boards, which had raised the necessary assessments, the Board of Directors attempted to impose uniformity and efficiency in local jails while separately maintaining sole responsibility for the management of the general prison at Perth. This form of administrative structure was unique, and differed from England where local prisons were not brought under close central supervision before 1865 .

South of the border the Home Office possessed no authority to enforce sanctions, but through the efforts of the prison inspectors appointed in 1835, it persuaded a number of local authorities in England to remodel or rebuild their prisons in conformity to the separate system. Some magistrates resisted the official adoption of designs and rules which often involved large expenditures they were unwilling to impose on the rate payers. Consequently, throughout the period 1835 to 1865 , in contrast to the situation in Scotland, local prisons in England were marked by a lack of uniformity in construction, diet, and discipline as standards were often dictated by the views of each prison governor appointed by the magistrates. This "quest" for uniformity continued in 1865 when a Prisons Act required local jails to provide separate cells commensurate with the highest number of prisoners

*I would like to thank the American Philosophical Society and the University of Puget Sound for their financial support for this research project.

' 2 and 3, Vict., Ch. 42, An Act to Improve Prisons and Prison Discipline in Scotland, 1839. 7 and 8 Vict., Ch. 34, An Act to Amend and Continue to 1st September 1861 "The Law in Respect to Prisons and Prisons and Prison Discipline in Scotland," 1861. 
held there, to follow a uniform code of rules, and to enforce hard and unproductive labor. Many magistrates were still able to avoid these regulations and the victory of uniformity came only in 1877 when legislation centralized all prisons in the country and placed them firmly under the control of the Home Office. ${ }^{2}$ Scottish prisons had, however, since 1839 experienced some degree of centralized control that had attempted to bring uniform standards to all the jails in the country.

By the mid-1830s it was clear that burghs in Scotland, which were, in part, responsible for the imprisonment of all criminal and civil prisoners in the country after convictions, were no longer able to fulfil this obligation. ${ }^{3}$ Many of the burghs were small and lacked the financial base to provide adequate penal facilities; furthermore, no legislation existed enabling them to raise assessments by which to improve the situation. During the eighteenth century, counties could raise funds under "Rouge money," but this provided only for the apprehension, prosecution, and accommodation of prisoners before trial. Some counties, cognizant of the inadequacy of the burgh jails, did give assistance by voluntary local acts or help with the erection of bridewells and county prisons when no burgh jail existed in the locality. Nevertheless, these local efforts were very uneven, and even many county jails were often as "ruinously imperfect" in discipline and accommodation as the burgh prisons.

The appalling condition of burgh jails was verified by a report of a Select Committee in 1818, undertaken after the burghs themselves had petitioned for relief. The Committee, noting that many of the jails were "insecure and incommodious," suggested that counties make an assessment for the provision of adequate jails in the country. This inquiry enabled Commissioners of Supply to give aid to burgh jails, but because the legislation was only permissive, many counties ignored it. ${ }^{4}$

${ }^{2}$ Studies of nineteenth century English prisons incl $\rightarrow$ : U.R.Q. Henriques, "The Rise and Decline of the Separate System of Prison Discipline," Past and Present 54 (1973):61-93; Margaret E. DeLacy, "Grinding Men Good? Lancashire's Prisons at Mid Century," in Victor Bailey, ed., Policing and Punishment in Nineteenth Century Britain (London, 1981), pp. 182-216; Michael Ignatieff, A Just Measure of Pain (New York, 1978); Sean McConville, History of English Penal Administration: 1750-1877 (London, 1981); M. Heather Tomlinson, "Design and Reform: The 'Separate System' in the Nineteenth Century Prison," in Anthony D. King, ed., Buildings and Society: Essays in the Social Development of the Built Environment (London, 1980), pp. 94-119; : $\rightarrow$ idem., "Prison Palaces': A Re-Appraisal of Early Victorian Prisons, 1835-77," Bulletin of the Institute of Historical Research 51 (1978): 60-71.

${ }^{3}$ First Report of the Board of Directors of Scottish Prisons, PP, Vol. 26 (1840), p. 3.

'Ibid., pp. 5-9;50. 
The still-intolerable state of Scottish jails led Sir William Rae, the Lord Advocate, to instigate another Select Committee investigation in 1826 to remedy the situation. Rae wanted the magistrates in the counties to cooperate with the burghs to construct new prisons, or, if the burghs refused to take the responsibility themselves, to draw from funds raised by an assessment for that purpose. Rae's report, published in 1830, produced the same litany of complaints about the poor discipline, lack of work, and absence of moral instruction which prevailed in the burgh prisons. These criticisms were reiterated even more forcefully by the Commissioners inquiring into the state of the Municipal Corporations in 1835. Concluding that burgh jails were in a "wretched state," they recommended that the smaller prisons be abolished or incorporated into unions, that long-term prisoners be accommodated in five or six district prisons located throughout the country, and that these prisons be supported by a new asessment based on the value of real property throughout the entire country. ${ }^{5}$

It was in this atmosphere of crisis that Frederic Hill, appointed as Scotland's first prison inspector in 1835 , called vociferously for a decisive change in penal bureaucracy in Scotland. In his first four reports he provided a comprehensive survey and a scathing condemnation of prison conditions that he considered worse than those in England. ${ }^{6}$ Hill was critical of local authorities who permitted unhealthy conditions and poor discipline. There was a lack of uniformity in treatment and the standard of less eligibility was ignored. ${ }^{7}$ He stressed that burghs and counties had failed to agree to a suggestion to cooperatively construct new burgh jails. ${ }^{8} \mathrm{He}$ noted that although some counties had made efforts to improve buildings, on the whole the country gentry had been unwilling to raise the necessary funds: "Gentlemen who undertake the necessary duties often have other and various duties to attend to, which it would be unreasonable to expect them to set aside for the sake of the prison." Hill painted a picture of

'Ibid., pp. 10-12.

${ }^{6}$ Hill reported: "Want of the means of separating prisoner from prisoner, and of preventing intercourse from without; want of employment, and of a provision for teaching the prisoners a trade or other occupation, by which to earn an honest livelihood when restored to society; want of mental, moral, and religious instruction; insecurity; the luxurious diet and life of ease in some prisons compared with the food and labour of the lowest class of honest and industrious people; great expense of many prisons; incompetency of many keepers; want of female officers; want of means of inspection; want of cleanliness and ventilation; sloth and injury to health, induced by the long time prisoners pass in bed, and want of a uniform system." First Report Inspectors of Scottish Prisons, PP, Vol. 32 (1836), p. 13.

'Frederic Hill, An Autobiography of Fifty Years in Times of Reform, edited with additions by his daughter, Constance Hill (London, 1894), pp. 11, 129.

'Ibid., p. 9. 
magistrates unwilling to remove incompetent personnel and prone to "apathy, dilatoriness, and a yielding to local influence." These magistrates, drawn from the ranks of the country gentry, had no knowledge of penal conditions, raised opposition to Hill on his early visits. Only threats of legal action by Hill forced some of the magistrates to consider appointing competent keepers and staff. As a solution to these long standing problems, Hill proposed the abolition of local control over prisons and the establishment of "one directing authority" appointed by the central government. ${ }^{10}$ This general management would construct and be responsible for several large penitentiaries which would receive prisoners after trials from smaller jails on the circuit. ${ }^{11}$ Burgh jails would be abolished entirely and the government would purchase Glasgow Bridewell, Fort George, and the military prison at Perth for the core of the national system. ${ }^{12}$ A lunatic asylum and a reformatory would be established under the control of the new penal administration. This plan, he felt, would radically reduce the cost of Scottish prisons, as uniformity in personnel and construction would provide economies of scale and supplies could be purchased on contract in bulk. The general penitentiaries would be supported by a prison fund in the hands of the government but "raised by a general rate on land and houses all over Scotland, to fall equally on all classes." 13

Hill's proposals were initially adopted for legislative action. In 1837, Fox Maule, the M.P. for Perthshire and Under Secretary of State, introduced a bill in the House which he admitted rested heavily on the principles and suggestions of the inspector, and Hill was given the credit for preparing an abstract of the legislation. ${ }^{14}$ Maule was convinced that the state of Scottish prisons was so bad that centralization was the only way to enforce reform and uniformity. The bill proposed that the control held by the counties and burghs over their prisons was to be relinquished and pass into the hands of a Board of Directors, which would "possess and exercise full power of the administration and management of all prisons in Scotland," 15 and which would be directly responsible to the Home Office. The central board was empowered to sell old prisons, make renovations or construct new buildings, remove prisoners from any jail, and appoint and dismiss all local prison personnel. The legislation envisioned well-regulated prisons

\footnotetext{
'Second Report, Inspector of Prisons, PP, Vol. 32 (1837), pp. 766, 771.

${ }^{10} \mathrm{Hill}$, Autobiography, pp. 130-131.

${ }^{11}$ First Report, PP, Vol. 25 (1836), p. 18.

${ }^{12}$ Second Report, $P P$, Vol. 32 (1837), p. 778.

${ }^{13}$ First Report, PP, Vol. 25 (1836), p. 19, and Second Report, PP, Vol. 32 (1837), p. 777.

${ }^{14}$ Hansard, Vol. 37 (1837), pp. 1201-03.

${ }^{15}$ Ibid., p. 13.
} 
established in circuit towns, and the construction of new penitentiaries, on land purchased from the government, for prisoners serving long sentences. Inspection was to be carried out by local officials who were to submit annual reports to the Board of Directors. This system was to be funded by an assessment on the counties and burghs based on their respective populations and levied against both property and rental values. ${ }^{16}$

This radical administrative solution to the condition of the prisons, however, was quickly subjected to serious criticism in the House. Although Fox Maule tenaciously clung to the principle of centralization, the Scottish gentry in 1838 forced him to compromise on the legislation in a House Committee. Peel opposed the legislation on the grounds that the counties had to retain some role in the management of prisons. Moreover, he felt that it was unconstitutional to force an assessment on the property owners without providing them any form of representation. Peel was afraid that this action would further alienate the gent: $y$, who had already "so much withdrawn themselves from all public bodies." The advantages of a central board, he declared, "would be purchased at too high a price." Other critics disliked local funds going to support three centrally controlled experimental penitentiaries, and opposed the introduction of a general assessment which made little reference to expenses incurred by each county. ${ }^{17}$

This opposition to the legislation was a source of concern to Viscount Melville, who became the first Chairman of the Board of Directors in 1839. He disliked the suggestion that county prison boards be established to work with the General Board: a compromise made by Fox Maule to pacify the county interests. Melville complained this arrangement meant the construction of a jail in every county that would necessitate the immediate refurbishing of some thirty prisons and create large operating costs. Melville urged Fox Maule to delay the legislation in order that ten major district prisons could be established without reference to any traditional local administrative interests but to the towns that held circuit courts. ${ }^{18}$ Scotland thus would be able to abolish its numerous smaller jails and to take advantage of a simplified and cheaper penal system. ${ }^{19}$ His suggestion received an angry

${ }^{16}$ Ibid., pp. 7-13, 29-30.

"Hansard, Vol. 42 (1838), pp. 426-437; Vol. 44, (1838), pp. 632-633; ibid., Vol. 47 (1839), pp. 345, 1324-36; Vol. 48 (1839), pp. 1157-1158.

${ }^{18}$ Melville to Fox Maule, 16th April 1840, Melville Papers, 354 A/130, National Library of Scotland; see also Secretary of the Board of Directors to the Lord Advocate, 22 April 1840, Scottish Record Office, HH/7/1.

${ }^{19}$ Melville to Fox Maule, 29 April 1840, Melville Papers, 354 A/149; and observations on W. Rae's notes on Scottish Prisons made by Melville, 6 July 1840, Melville Papers, 354 A/177. Melville noted that there were only 40 counties with one jail each in England serving some 13 million persons. Scotland had 34 counties (with a proposed county jail) serving only 2,300,000 persons. Assizes were always held in every English county town but this was not always the case in Scotland. 
response from the county members backed by Sir William Rae, who accused Melville of forcing uniformity and centralization on the counties. Melville, without accepting any of the logic of the opposition, nevertheless was willing to accept a compromise where the counties retained the option to form unions for joint prisons. ${ }^{20}$ Melville saw himself as only a reluctant centralizer confronted by "dogged resistance" of the landed interest who refused to support burgh jails, but saw that it was unwise to incur their wrath as the General Board would need all the cooperation it could get from the counties. ${ }^{21}$ Although Fox Maule abandoned a District Prisons Bill, even the permissive legislation to allow for the creation of unions was greeted with opposition. The General Board found this attitude almost irrational but made it clear to the counties that the decision to form unions was solely theirs. ${ }^{22}$

Although for different reasons, Hill, too, was disappointed with the bill. Two years of delay in parliament had made justices reluctant to embark on construction of new prisons, thereby worsening the problem of overcrowding and causing an administrative crisis. He claimed that the original bill had been injured in the three readings in the House, as the county boundaries had remained intact and county jails had been established in every county, which left penal administration open to manipulation by separate interests that could succumb to charity and patronage. Leaving all control and appointments in the hands of the General Board, he felt, would have freed the system "from local ties and feelings," although he expressed the conviction that the Board would have consulted local experts in prison discipline. ${ }^{23}$

The outcome of this debate was the eventual passing of a Prisons Bill in 1839 which was a judicious compromise between the local and central authorities. According to this Act, a General Board of Directors of Scottish prisons received a temporary commission to supervise the construction and discipline of all prisons in the country. Fourteen unpaid members appointed by the Home Secretary, drawn from the peerage, gentry, lawyers, or ex officio law officers, were to serve under a chairman and be assisted by a salaried permanent secretary. Throughout the 1840 s and 1850 s conscientious chairmen, hardworking secretaries, and board members working in various committees enhanced the efficiency of the Board. Each committee

\footnotetext{
${ }^{20}$ Murray to the Lord Advocate, 22 April 1840, SRO, HH/7/1.

${ }^{21}$ Melville's observations on Rae's notes, 6 July 1840, Melville Papers, 354 A/177 and Murray to the Lord Advocate, 22 April 1840, SRO HH/7/1.

${ }^{22}$ Murray to Alex Thomson, 29 June and 6 July 1840, SRO HH/7/1.

${ }^{23}$ Fifth Report Inspector Scottish Prisons, PP, Vol. 26 (1840), p. 12.
} 
could act without the consent of the full Board, thus aiding in the delegation of responsibility and avoiding useless discussions, obstructionism, and compromised decisions that might have ensued from such a large membership. ${ }^{24}$ The Secretary of State was kept informed as to the decisions of the Board through its annual report, which he presented to Parliament. The General Board was to enlarge the prison at Perth for prisoners sentenced to over six months and was to have direct control over management of its land and personnel. The Directors received the right to move any prisoner in Scotland from one jail to another or to a lunatic asylum, if necessary. ${ }^{25}$

The object of the legislation was to promote cooperation between the General Board and the counties. County Prison Boards were to be established under the supervision of the General Board, and all the property and responsibility once held by burgh and county jails were to pass to them in 1840. The General Board retained the right to "authorize County Boards to discontinue, sell, dispose of any prison or rebuild, or erect and provide new prisons." The County Boards were obliged to maintain "superintendence and management" of discipline and conditions. The General Board, however, was to ensure that all Scottish prisons should "train prisoners in good and industrious habits by effecting their complete separation from vicious society, and by affording them religious and moral instruction ...." The County Boards were subject to the orders and rules issued by the General Board, which retained the right to suspend or dismiss keepers in local jails. If any county failed to appoint a board or failed to carry out the Act, the General Board could assume its functions. ${ }^{26}$

The Prisons Act of 1839 also directed the General Board to draw up man-

\footnotetext{
${ }^{24} \mathrm{An}$ attempt had been made during debate on the bill to appoint nine directors that excluded the prison inspector to be nominated by nine local boards. See Hansard, Vol. 42 (1838), p. 1421, and Vol. 47 (1839), p. 1230. See Henry Parris, Constitutional Bureaucracy (London, 1969), pp. 82-87, for a discussion of the use of boards in Victorian administration. Fifteen new boards were created between 1832 and 1855. Peers that served as Directors included: Lord Elcho, the Marquess of Breadalbane, Earl Dalhousie, Fox Maule (Earl Dalhousie), Earl Rosebery, Viscount Melville, Lord Belhaven, Lord Ivory, Earl of Mansfield, Lord Dunfermline, Lord Dalmenay, Sir William Rae, Bart, Sir Alex Charles Gibson Milner, Bart, 22nd Report, Directors of Scottish Prisons, Vol. 555. The ex officio members were to include the Lord Advocate, the Solicitor General, the Dean of the Faculty of the University of Edinburgh, the Sheriffs of Edinburgh and Perthshire. An Act in 1851 removed the Prison Inspector, the Lord Justice General and the Lord Justice Clerk as ex officio Directors. Viscount Melville acted as Chairman from 1839 to 1852 and John Gordon from 1852-1860. Ludovic Colquhoun was Secretary from 1843 to 1854 and John Hill Burton from 1854 to 1860 . The continuity of the Board was further assisted by Mr. Gould, Chief Clerk between 1839 and 1859. 16th Report, PP, Vol. 26 (1854-5), p. 24.

${ }^{25} 2$ and 3, Vict., Ch. 42, Clauses 16-19.

${ }^{26}$ Ibid., Clauses 19 and 28.
} 
datory assessments raised by the Commissioners of Supply in the counties and the magistrates in the burghs. In addition to the $£ 2000$ annual assessment for building the General Prison at Perth, each county was to raise funds for the running expenses of the General Prison according to its population and number of prisoners it sent there. The counties were also forced to raise an assessment for building and altering prisons in their localities. The General Board fixed the scale of these assessments. Additional assessments for building could be raised with the approval of the General Board if the counties so wished; the monies would be advanced from the Scottish banks on security of these levies raised over seven years. Any assessment for the day-to-day running of local prisons was left up to the counties themselves. The building at Perth would be funded by the Treasury, but also by supplementary assessments fixed by the Board on the counties and burghs. ${ }^{27}$

One can only speculate why initial resistance to centralization was weaker north of the border, but it is clear that the Prisons Bill of 1839 was the result of the well-publicized conditions of Scottish jails, that clearly pointed out the long recognized failure of Scottish local administration to improve conditions. The support of key individuals in the admiistration was gained and after concessions had been made, the Scottish gentry were forced to accept a general assessment for building prisons under the administrative direction of the General Board.

An examination of penal and poor law policies in Scotland shows that there was no peculiarly Scottish component in the drive toward administrative uniformity. In the case of prisons, bureaucratic imperatives prevailed which demanded uniformity and centralization, while in poor law policy existing administrative arrangements were not fundamentally disturbed. The Poor Law provided inadequate relief as the system rested on the principle of voluntary contributions collected in the parishes, which had exclusive control over all aspects of poor relief. ${ }^{28}$ The situation grew worse in the 1830s and early $1840 \mathrm{~s}^{29}$ as increased unemployment swelled the prison population in Glasgow and Edinburgh as able-bodied heads of household were not eligible for assessed funds. ${ }^{30}$

${ }^{27}$ Ibid., Clauses 29-47. Melville to Graham, 12 May, 11 October 1842; 23 April 1843, National Library of Scotland, 354 A/212, 232, 252.

"Audrey Paterson, "The Poor Law in Nineteenth-Century Scotland," in Derek Fraser, ed., The New Poor Law in the Nineteenth Century (London, 1976), p. 172; R.A. Cage, The Scottish Poor Law 1745-1845 (Edinburgh, 1981), pp. 90-110.

${ }^{29}$ Paterson, “The Poor Law," pp. 173-174; Cage, "Scottish Poor Law," pp. 126-140. For example see Grey to D. Cameron, 13 Feb. 1845; Waddington to MacLeod or MacLeod, 7 Dec. 1850; LeMarchant to the Provost of Paisley, 10 May 1848, HO 103/11.

${ }^{30}$ Eighth Report, Inspector Prisons, PP, Vol. 25 (1843), p. 443; Eleventh Report, $P P$, Vol. 20 (1840), p. 483. 
The Poor Law Act of 1845 established a Board of Supervisors to organize the appointment of some $\mathbf{8 8 0}$ parochial Boards. This system bore only a superficial resemblance to the administrative structure that existed between the Directors and the County Prison Boards. The Poor Law Board conducted itself in "a merely supervisory role" in contrast to the General Board, and it was left solely to the Parochial Boards to adopt legal assessments or to rely on voluntary contributions. There were no uniform standards for providing relief, and local diversity was encouraged by the Board as each parish considered relief applications individually. The Board of Supervisors was protective of local needs and identity and rarely moved against the parish's decision. Through regulations the Board could enforce the law, but by being more flexible than the General Board of Prisons the supervisors would reach a compromise with local authorites. Moreover, the traditional policy of denying the right to the able-bodied shunning any workhouse test based on less eligibility was continued as the localities reserved the right to build workhouses: the New Poor Law of 1834 was never adopted in Scotland. Hence the considerable administrative changes that resulted from the Prisons Act of 1839 were not replicated in the case of the Poor Law. The legislation in 1845 , which was equally the result of crisis, merely repaired and amended the existing system. ${ }^{31}$

\section{III}

Although Melville lamented the failure to establish a limited number of district prisons, and Hill was dissatisfied because complete centralization was rejected, the Board of Directors possessed considerable power to reform local prisons without removing their management and ownership from the local authorities. They administered an average daily prison population of 1,840 in 1840 . This number rose to a peak of 3,143 in 1849 but declined throughout the 1850 s to reach 2,083 in 1861 . The actual number of prisoners committed fell from 22,849 in 1851 to 19,192 in 1860 . The number sentenced to transportation, penal servitude, or imprisonment over six months also declined. The majority of prisoners in Scotland were placed in jail for short periods of time, and a sizeable minority of prisoners were recidivists. ${ }^{32}$

\footnotetext{
${ }^{31}$ Paterson, "The Poor Law," pp. 175-184; Cage, "Scottish Poor Law," pp. 140-143.

${ }^{32}$ Prisoners sentenced to imprisonment from 6 months to 3 years for 1851:1226; 1856:970; 1861:613. Prisoners sentenced to penal servitude or transportation for 1851:432; 1856:336; 1861:207. Prisoners imprisoned for indefinite periods: $1851: 3,390 ; 1856: 4,357 ; 1860: 5,366$. Prisoners imprisoned for less than six months: $1851: 12,561 ; 1856: 11,573 ; 1860: 9,695$. Previous imprisonments in the same prison: $1851: 35.23 \% ; 1856: 40.71 \% ; 1860: 47.41 \%$ of the total committals in each year. Between $13 \%$ to $14 \%$ of these prisoners were in jail for the second time. Twenty-Second Report, Board of Directors, PP, Vol. 29 (1862), pp. 561-581.
} 
In the twenty years after passage of the Prisons Act of 1839 substantial changes were made in the administration of the Scottish penal system. A schedule of assessments was drawn up for each county in cooperation with the General Board. Initially, only a few burghs tried to hold onto their traditional rights or complain openly about the level of taxation..$^{33}$ Consequently, a large building program was launched in the 1840 s with the General Board carefully supervising, reviewing, and certifying new projects submitted by the County Boards. The intention was to establish one firstclass prison that conformed to the separate system and well-conducted second-class prisons and lockups in every county for short-term prisoners or persons awaiting trial. ${ }^{34}$ Magistrates issued a warrant determining the class of each prisoner and the General Board rigorously stipulated what classes of prisoners could be legally received in each prison or lockup. Between 1839 and 1860 the General Board exercised its power to reduce the number of prisons in Scotland from 170 to 72 . Thirty-eight new prisons were built, an additional eleven were rebuilt on old sites, and fourteen were enlarged and improved. These improvements were financed by $£ 166,524$ in ordinary assessments and $£ 86,807$ in additional assessments that the General Board urged the counties to raise. ${ }^{35}$

This impressive program of prison construction and renovation was tied to the Directors' unflagging faith in the efficacy of the separate system and by 1860 the Directors were able to say that each Scottish county had "sufficient separate and suitable accommodation for all prisoners." ${ }^{36}$ The reports of the Inspectors in the $1850 \mathrm{~s}$ confirmed that the Scottish system had achieved a considerable level of uniformity. By 1861 only Kirkcudbright, Stirling, and Perth county prisons had continually failed to adopt changes to accommodate the separate system. ${ }^{37}$ By 1861 , a decrease in prisoners caused the General Board to call a halt to the expansion of several previous-

\footnotetext{
${ }^{33}$ Secretary of the General Board to Fox Maule, 11 Feb. 1841, SRO, HH/7/3, Melville to Graham, 7 March 1842, NLS, 354A. Second Report, Board of Directors, PP, Vol. 11 (1841), pp. 9-10.

${ }^{34} 2$ and 3, Vict., Ch. 42, Clause 19.

${ }^{35}$ Twenty Second Report, Board of Directors, PP, Vol. 29 (1861), pp. 356-359. Seventeen counties had applied for additional assessments by 1847 under 2 and 3 Vict., Ch. 42, Clause 36, and 25 by 1851 . Ninth Report, PP, Vol. 34 (1847-8), p. 135; Melville to Campbell, 19 April 1851, GD 55.5, SRO 164/3.

${ }^{36}$ Twenty Second Report, PP, Vol. 29 (1861), p. 539.

${ }^{3}$ Fifteenth Report, $P P$, Vol. 32 (1854), p. 120; Sixteenth Report, PP, Vol. 24 (1854-55), p. 191; Eighteenth Report, PP, Vol. 7 (1857), p. 594; Nineteenth Report, PP, Vol. 30 (1857-58), p. 551, Twenty Second Report, PP, Vol. 29 (1861), p. 533, and for example see Twentieth Report, Inspector of Scottish Prisons, PP, Vol. 26 (1854-5), "Scottish prisons are in their usual excellent order, and prison rules generally observed," p. 129.
} 
ly recommended prisons. Building assessments were discontinued for the twenty-four counties in 1859 , and $£ 8604$ in unspent funds raised for construction were returned to the localities when the General Board was dissolved in $1861 .^{38}$

The General Board, successful in promoting a measure of uniformity in prison accommodation and construction, was also able to frame and enforce an elaborate code of rules for local jails in Scotland. The Directors had the power to suspend or dispense with any rule. In 1847 and 1853 they drew up extensive codes for the County Boards to put into operation. The subjects covered in the general rules included drainage, visitation rights, conduct of governors, prevention of escapes, ventilation, duties of chaplains and surgeons, smoking, shaving, clothing, work, exercise, and diet. ${ }^{39}$ The localities could not suspend or make any additional rules without the permission of the General Board, whose authority was subject only to the approval of the Secretary of State. In 1857 the County Boards were requested to submit a special return to confirm that the rules were being adhered to. The majority of local authorities had fulfilled their responsibilities, and the Prison Inspector in the 1850s, John Kincaid, felt they were on the whole willing to see that prison officials were following the rules. ${ }^{40}$

Penal administrators, in the late 1840 s, painted a picture of vastly improved discipline in local jails. Hill remarked on the stricter supervision and the low incidence of physical punishment in Scotland. This more efficient regime he attributed to the power of the Directors who could, on the advice of reports made by the Inspector, remove incompetent governors and matrons. Hill may have been moved to hyperbole when he observed that a number of governors had been exemplary in their concern for the welfare of their charges and treated the prisoners with "filial attention" and kindness. ${ }^{41}$ The Prisons Act of 1839 declared that not only should prisoners in Scottish jails be subject to the separate system, but also that they should

\footnotetext{
${ }^{38}$ Twenty Second Report, PP, Vol. 29 (1861), p. 356; Nineteenth Report, PP, Vol. 30 (1857-58), p. 552; Twenty First Report, PP, Vol. 36 (1860), p. 12.

${ }^{39}$ Ninth Report, $P P$, Vol. 34 (1847-48), pp. 174-215 and Sixteenth Report, PP, Vol. 26 (1854-55), p. 196. For the difference between Scottish and English rules see Melville to Grey, 23 August 1847, PRO, HO 45, OS 1995.

${ }^{40}$ Eighteenth Report, Board of Directors, PP, Vol. 36 (1860), p. 15.

"Frederic Hill, Crime. Its Amount, Causes and Remedies (London, 1853), pp. 193, 283, 286, 307-8, 371, idem., Autobiography, pp. 277-278, 371. In 1860 the conduct of prisoners was classified: $21,235=$ good, $789=$ tolerable, $255=$ bad. Of the 20,026 received into Scottish jails only 802 were punished for misconduct, although of the 170 placed in irons 104 were females, 158 females and 286 prisoners were placed in dark cells. See Twenty Second Report, Board of Directors, PP, Vol. 29 (1861), pp. 561-570.
} 
be employed in useful labor. Productive labor was introduced in the $1840 \mathrm{~s}$ and was made attractive to the prisoners by the provision of incentives through overwork and piece rates. Hill, a strong supporter of this utilitarian system, was especially impressed that the provision of artificial lighting allowed prisoners to work up to fifteen hours a day. ${ }^{42}$ Productive labor and some rudimentary education were essential elements of a system that aimed to be self supporting and to reduce the level of crime in the country. ${ }^{43}$

A closer look at the Scottish penal system in the 1840s, however, reveals the existence of some serious shortcomings that lay behind some of the blatantly optimistic statements of Hill and the tone of the reports of the Directors. Relations between the General Board and the County Boards were not always harmonious. Complaints came from the burghs which felt their share of the prison assessment was too high in comparison to the amount paid by the counties. Not only did the rate vary a great deal from town to town, but apparently those towns with large populations but with a weak economic base were asked to pay the highest rate. ${ }^{44}$ This was clear in Stirling where the county had embarked on an ambitious building program and had imposed a levy for construction that was much higher than the cost of a recently erected city jail. The ratepayers were very angry at this situation and put up resistance to its collection throughout the $1840 \mathrm{~s} .{ }^{45}$

On the other hand there was only one occasion where the General Board refused to grant an assessment. The County Board of Edinburgh was refused an additional assessment after they had disastrously underestimated the cost of rebuilding their prison. ${ }^{46}$ The poor relationship between the General Board and the Edinburgh County Board, already fuelled by the latter's poor treatment of female prisoners and refusal to adopt a standard dietary, was now exacerbated. Edinburgh's town council led a strong attack on the proposed Prisons Bill of 1851 , which merely extended the period for repayment of additional assessments from seven to fourteen years, suggesting incorrectly to the ratepayers that the legislation intended to extend the "over-

\footnotetext{
${ }^{42}$ Thirteenth Report, Inspector Prisons (Northern District), PP, Vol. 26 (1847-48), p. 375; Hill, Crime, pp. 193, 206, 348, 283, 371; idem., Autobiography, pp. 277-8, 371. He praised Glasgow Bridewell which resembled a "well regulated manufactory."

${ }^{43}$ Second Report, Inspector of Prisons, PP, Vol. 32 (1837), pp. 773-77.

${ }^{4}$ See PP, Vol. 13 (1845), "Select Committee to inquire into the practical operation of the Acts $2 \& 3$, Vict., c 42, and $7 \& 8$, Vict., c 34, as far as the regulation of Assessment in Counties and Burghs is concerned."

"Findlay McKichan, "A Burgh's response to the Problems of Urban Growth: Stirling, 1780-1880," Scottish Historical Review 57 (1978): 76.

${ }^{46}$ Coloquhoun to Waddington, 25 March 1850, SRO, GD 45/9/158/59; to Fox Maule, 19 April 1851, SRO, GD 45/9/158/9.
} 
powering power of the General Board." 47

This modification, suggested by Melville, was necessary because a number of counties failed to collect enough funds for the payments due on the additional assessments. ${ }^{48}$ Members of the General Board were paid expenses to visit the counties involved to attempt to pry the money from them. When this failed, legal proceedings were taken against those who fell into arrears. Moreover, Melville pleaded successfully with the government to relieve the counties of the cost of maintaining the General Board as he felt the Board was a national not a local concern. Melville was also successful, despite reluctance from the Home Office, to get the Treasury to pay for the operation of the government prison at Perth instead of having to rely on funds from the localities. ${ }^{49}$

Despite the ambitious building scheme it was clear that even the recently completed structures were inadequate in face of the rising rate of committals. This resulted in overcrowding in the late 1840 s and early 1850 s and prevented the uniform imposition of the separate system..$^{30}$ The Board and the inspector complained that separation was not enforced in most of the largest jails although it was best carried out in the smaller institutions. ${ }^{51}$ Glasgow, for example, in the late 1840s, after the death of a fine governor, had lost sight of the separate system since the new governor was more concerned with the possibility of profit from prison labor. In Edinburgh female

${ }^{47}$ The Lord Provost to Melville, 27 March 1851, SRO, GD 51.5/162; Melville to the Lord Provost, 28 March 1851, Ibid; and Melville to Bruce 10 and 15 April 1851, Ibid; 163/4.

${ }^{48}$ Melville to Graham, 23 April 1843, NSL, 354A/252; Melville to Richardson, 17 January 1851, SRO, GD 51.5, 161/1; Melville to Bruce, 10 April 1851, SRO, GD 51.5, 164/1. For example, there was need to recover money from Renfrewshire: Secretary of the General Board to William Davie, 30 September, SRO, HH/7/11. Legal proceedings were moved against Fife, Ross and Cromarty, Ninth Report, PP, Vol. 34 (1857-8), p. 151.

${ }^{49}$ See $7 \& 8$ Vict., Ch. 34, Clause 1, and Melville to Graham, 12 May 1842, 11 October 1842; 23 April 1843, NSL 354A/212, 232, 252. The counties were also relieved of the expenses of criminal lunatics and for the maintenance of all prisoners convicted to trial by a jury or before the court of Justiciary. Grey to the County Prison Boards, 18 January, 1848, PRO, HO 45, OS 833; Trevelyan to the Home Office, 6 November, and the Lord Advocate to the Home Office, 11 December 1847, HO 45/2015.

${ }^{30}$ For example, there were two good prisons in Fife at Culpar and Dunfermline but the increase of population and crime had made them inadequate. The new prison at Culpar was constructed in the mid 1840s with accommodation for between forty and fifty separate cells. Melville to Campbell, 19 April 1851, SRO, GD 51.5, 164/3; Melville to Graham, 22 My 1843, 354A, NLS 260. Committals had reached 25,850 per annum by 1851 . See Seventeenth Report Inspector of Scottish Prisons, PP, Vol. 52 (1851-2), p. 269.

"Eleventh Report, Board of Directors, PP, Vol. 29 (1850), p. 460; Thirteenth Report, Inspector of Scottish Prisons, PP, Vol. 26 (1847-8), p. 514; Fifteenth Report, PP, Vol. 28 (1850), p. 797; Sixteenth Report, PP, Vol. 27 (1851), p. 840. 
inmates were kept with each other in overcrowded cells. The General Board was so disgusted with the county's unwillingness to respond to their suggestions and to "the common dictates of humanity" that it recommended to the Secretary of State that the Treasury should withhold its payment to the prison. $^{52}$

At the center of the crisis of overcrowding lay the inability of the government prison at Perth to accommodate prisoners sentenced to long terms. There was a tendency for sheriffs to assign to Perth a large number of prisoners sentenced beyond six months as the local jails were in such poor condition. As a result of a miscalculation by Hill, there was not enough accommodation for males at Perth, and Melville wanted sheriffs to stop sending prisoners sentenced for less than a year to the prison. Legislation was passed in 1843 so the General Board was given the right to determine which prisoners should be admitted to Perth, and they naturally refused to admit those who were serving the shortest sentences. The Board also acquired the right to send prisoners sentenced to one year and beyond, who had previously gone to Perth, to any other prison. ${ }^{53}$ This right proved to be a cause of tension as the crisis of accommodation intensified in 1848 .

The separate system broke down as a large number of long-term prisoners were housed in local jails; in 1847, 148 prisoners receiving sentences above one year were turned away from Perth, and in 1848, 1,100 requests from the counties to house prisoners at Perth were rejected by the Board. ${ }^{54}$ The Lanarkshire County Board (forced to accommodate 125 government prisoners) was unwilling to raise an additional assessment for the extension of Glasgow jail as they felt funds should come directly from the Treasury. ${ }^{55}$ The same source of resentment lay behind Edinburgh's lack of cooperation with the Board in the 1850s. They blamed the neglect of female prisoners on the government which had refused to remove a number of women under long prison sentences awarded in lieu of transportation..$^{56}$

In response to this crisis suggestions were made to build another national

\footnotetext{
${ }^{32}$ Secretary of the General Board to William Davie, 23 June 1847, SRO, HH/7/11 and to Waddington 14 January 1851, GD 45/9/158.51; Twelfth Report, Board of Directors, PP, Vol. 29 (1847), p. 531; Thirteenth Report, PP, Vol. 36 (1847-48), p. 342.

${ }^{33}$ Melville to Graham, 5, 25 May and 11 October 1842, NLS, 354A, pp. 223-4; 7 \& 8 Vict., c 34, Clauses 4 \& 6.

${ }^{54}$ Melville thought "it is impossible to carry into effect to any adequate extent, the principle of separation which was contemplaated in the Scottish Prisons Act of 1839." Melville to the Home Office, 2 October 1848, PRO, HO 45, OS 833. See also Ninth Report, Board of Directors, PP, Vol. 34 (1847-8), p. 128; Tenth Report, PP, Vol. 26 (1849), p. 497.

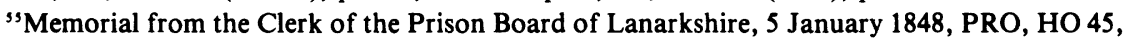
OS 833.

${ }^{36}$ Melville to Sheriff Gordon, 4 January 1850, SRO, GD 51.5, 160.
} 
prison in the Glasgow area to meet the needs of a growing population. Sir Joshua Jebb, the Surveyor General of English Prisons, on a visit to Scotland suggested, as did Lanarkshire, that a new prison in the west of Scotland was the only way to reinstitute the separate system in the country. The Board, on the other hand, was willing only to sanction building a new wing at Perth. Once the wing, which housed 200 prisoners, was completed in the early $1850 \mathrm{~s}$, the situation eased considerably and the separate system was better maintained as the number of prisoners in local jails decreased year by year. ${ }^{57}$ Although pressure on prison accommodation decreased, the recruitment of qualified subordinate officers appears to have been slower, and a number of escapes in the 1850 s were made in collusion with prison officers. As late as 1867 the Managers had to stress that officers be respectable and tidy, and warned them not to read on duty but rather to be busy and on the lookout for irregularities. ${ }^{58}$

Not only did the Prisons Bill of 1839 create some severe problems for its administrators, but its applicability was also seriously questioned by the Law Officers and even the Board of Directors itself. For example, the Lord Justice Clerk, although sensitive to the improvements that had been made in the system, felt "it would be chimerical to hope that any general reformation of offenders will or can be effected." "59 The Bench saw the separate system and the program of religious and moral instruction as insufficient deterrents: "Imprisonment is a punishment which has no terror for the bulk of offenders." ${ }^{60}$ Contrary to the opinion of experts like Hill, many believed that crime was truly on the increase and that society was plagued by young offenders released repeatedly from jail. The law officers, believing that the majority of the population saw prison as a place of comfort and luxury, pleaded for an extension of the use of transportation to the colonies. ${ }^{61}$ As the decade wore on, such comments became increasingly similar to the tone of the General Board.

Initial optimism at the success of the system soon faded, and the Directors conceded that the new legislation had not checked the recidivism rate,

${ }^{57}$ Melville to the Home Office, 2 October 1848, PRO, HO 45, OS 833; Melville to Sheriff Gordon, 4 January 1850, SRO, GD 51.1/160; Twelfth Report, Board of Directors, PP, Vol. 28 (1851), p. 513.

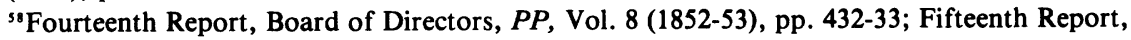
$P P$, Vol. 32 (1854), p. 98; Sixteenth Report, PP, Vol. 26 (1854-55), p. 219. Seventh Report, Managers of Scottish Prisons, PP, Vol. 35 (1867-68), p. 877. There was a request that prisons close one hour earlier to relieve of ficers who were away from home for 14 to 15 hours a day. Sixteenth Report, Board of Directors, PP, Vol. 53 (1852-53), p. 254.

${ }^{59} P$, Vol. 7 (1847), p. 79.

${ }^{60}$ Ibid., p. 74. See also pp. $63-82,115,372-8$.

${ }^{61}$ Ibid., pp. 80-82, 95, 351. 
as "most find it not that oppressive and wait for their discharge." were also willing to admit to the growing public distrust of the system, which was confirmed in 1844 by a report authorized by the Home Office and prepared by Sir Joshua Jebb and William Crawford, an English prison inspector. These officials observed during a visit to Perth that the discipline there was "more characteristic of an institution having simply in view the object of benevolence, than of a prison, the design of which is to punish as well as reform." Jebb and Crawford strongly recommended "such an alteration in the discipline as will render [the prisons] objects of fear and aversion, and restore to them their proper character of places of punishment." ${ }^{63}$ These sentiments reflected the opinion of the Home Secretary Sir James Graham, who, as early as 1842 , admitted to Melville that he favored transportation which would lead to the removal of "this scum," as he had "no great faith in the efficacy of reformatory prison discipline." Graham was convinced that the Scottish system lacked the truly penal aspect of hard labor. The principles of the reformatory system rendered jails to be hardly less comfortable, in his view, than workhouses. Graham asked the General Board to make some changes consistent with the principle of deterrence and fear as punishment, thus to render prison "a terror to evil doers."

The General Board defended its role in the evolution of the system. They informed Graham that they had only been instructed to carry out the specific terms of the Act, which aimed "to improve the character of the prisoners, by strengthening their social feelings and affections." Correspondence and visits from friends and relatives had been permitted in order to promote these affections and to "soften the character." Hence, the Board argued forcefully to the Home Office, they were strictly bound by the law and could not impose hard labor even if they had wanted to do so. Nevertheless, they said the Directors had been willing to give the law a fair trial, "and if it has failed, such failure is not to be imputed to the measures adopted by the Board, but to the system they were called upon to enforce." ${ }^{65}$ Discouraged by Graham's assault on the "spirit and letter of the Scottish Prisons Bill," Hill felt it was "an attempt to undo half the good that has been done in Scotland in prison discipline," by forcing the Directors to assimilate their rules with those in operation in England. Hill bitterly reproached Graham's suggestions to weaken the power of the governor and

\footnotetext{
${ }^{62}$ Minutes of the Board of Directors to the Home Office, 12 May 1844, PRO, HO 45, OS 833 and 13 September 1849, PRO, HO 12/5/460.

${ }^{63}$ Ibid., 12 May 1844, and quoted in the Board of Directors to the Home Office, 5 december 1844; Ibid.

${ }^{64}$ Graham to Melville, 7 March and 14 October 1842, NLS, 354A/240.

${ }^{65}$ Melville to the Home Office, 2 October 1844, PRO, HO 45, OS 833.
} 
introduce "useless" labor under the guise of so-called "improvements."

Melville blamed the failure of the reformed system on administrative problems that prevented the efficient operation of a system of penal discipline. Although he was willing to agree with Hill that since the passing of the Prisons Act the majority of institutions had improved to an "extraordinary degree," nevertheless the evils remained "irredeemable." After observing the failure of the District prisons, Melville was convinced that it was impossible for the General Board to oversee the large number of County prisons and small Scottish jails. He told Graham at the Home Office that it was inconceivable to expect "an efficient system, with all its appendages described in your rules" to be adopted in Scotland. ${ }^{67}$

The most notable sign of the shift towards greater deterrence and that the reformatory system was being consciously abandoned was the introduction of hard labor into Scottish prisons. Both Sir Joshua Jebb and John Kincaid, the new prison inspector, suggested the introduction of the crank in 1849 to provide more severe punishment for short-term offenders. This machine, essentially a contraption for grinding air that the prisoners operated by hand, was introduced on an experimental basis at Perth and eight county prisons for short-term offenders. ${ }^{68}$ In 1849 a supplementary rule which Hill had strongly supported was promulgated that abolished overwork. The Directors, with the agreement of Kincaid, insisted upon "the necessity of care being taken that undue importance be not attached to profit arising from the earnings of prisoners" to the detriment of discipline in jail. ${ }^{69}$

By 1850 the Board was convinced that the crank should become a permanent feature in all prisons in the country, because it was thoroughly disliked by the prisoners. This move toward greater deterrence was no longer applied only to short-term offenders as the sentence of imprisonment with hard labor now became an option open to the magistracy. It was thought that productive labor was useless for some professional thieves, and those

\footnotetext{
${ }^{66}$ Hill, Autobiography, p. 242.

${ }^{67}$ Melville to Graham, 22 May 1843, NLS, 354A.260.

${ }^{61}$ General Board of Directors to the Home Office, 13 September 1849, PRO, HO 12/5/60; Melville to Campbell, 19 April 1851, SRO, GD 51.5/164/3; see also Board of Directors to Manners Sutton, 21 January 1846, SRO, HH/10. Legal opinions were sought out and it was assumed there was little need to change the law to accommodate the use of the crank. "Useful Labour" was interpreted by them to mean that it was useful to the prisoner after liberation. Thus, for short term prisoners the crank was an acceptable alternative to idleness as it promoted the correct attitude towards work. Board of Directors to the Lord Advocate, 26 December 1849, SRO, GD 45/9/158./22; Tenth Report, Board of Directors, PP, Vol. 34 (1847-8), pp. 513-5.

"Ibid., Eleventh Report, PP, Vol. 29 (1850), p. 460.
} 
"hopeless characters" should be put to work on the crank. ${ }^{70}$ Kincaid summed up succinctly this change of attitude: "Exclusive useful employments for all classes of prisoners has hitherto been the error of the system in this district." 11 Oakum picking was to be made available in those prisons where a crank had not yet been introduced. As if to further exemplify the move towards a stricter system, whipping was permitted for juveniles instead of short-term jail sentences. In addition, Kincaid was personally able to convince the Board to substitute wooden beds for hammocks for short-term prisoners. Hill openly criticized these changes as they represented a setback to reforming influences which he believed were for the worse in Scotland. ${ }^{72}$

Despite this shift towards a system of "sufficient stringency" in Scottish jails in the 1850s, however, fewer than fifteen percent of all sentences were awarded with hard labor. Most prisoners were still set to work on productive tasks and attempts were made to instruct prisoners in useful skills. The retention of productive labor was attractive to prison authorities since the sale of prison manufactures contributed between ten and twenty percent of the prisoner's maintenace. Male prisoners worked as shoemakers, tailors, weavers, and mat makers; females labored as milliners, dressmakers, and knitters. Only for criminal lunatics and debtors was work optional. In 1855 a full-time officer was employed at Perth to increase the sales and productivity of prison labor; authorities were concerned about the loss of productivity due to increased hard labor sentences and rising maintenance costs. Consequently, with the exception of hard labor prisoners, all the other Scottish prisoners "were employed, when practicable, at their own trades, and a large proportion of them were taught trades in prison which might be useful to them in after life." 73

\footnotetext{
${ }^{70}$ Ibid., p. 442; Thirteenth Report, PP, Vol. 26 (1847-8), p. 432; see also Board of Directors to the Home Office, 2 August 1850, PRO, HO 12/5/460.

Prisoners were to complete 14,400 revolutions on weekdays and would not be eligible for supper until they were completed. Those who broke prison rules were to be put on the crank: if they refused to perform on the machine they were placed in solitary on bread and water. Sixteenth Report, Inspector of Scottish Prisons, PP, Vol. 27 (1851), p. 842.

${ }^{7}$ Fourteenth Report, Inspector of Scottish Prisons, PP, Vol. 21 (1849), pp. 444-445; 14 \& 15 Vict., Ch. 7, section 6.

${ }^{72}$ Hill, Crime, pp. 194-206.

${ }^{73}$ Twenty Second Report, PP, Vol. 29 (1861), pp. 561-70. In 18608,758 males and 7,126 females were sentenced to jail $-1,100$ males and only 628 females received sentences with hard labor. Nineteenth Report, PP, Vol. 30 (1857-58), p. 587; Sixteenth Report, PP, Vol. 26 (1854-5), p. 206; at Perth in 1857 the gross cost of keeping a prisoner was $£ 19.2 .7$ and earnings from productive labor came to $£ 2.11 .0$ resulting in a net cost of $£ 16.117$ per annum. Two hundred prisoners were taught some skills each year and between 35-50 prisoners came to the prison with some skills already. Nineteenth Report, PP, Vol. 30 (1857-8), pp. 587-8. In Scotland the gross cost per prisoner ranged from $£ 15.12 .11$ in 1851 to $£ 20.17 .5$ in 1855; earnings from $£ 2.8 .0$ in 1854 to $£ 3.5 .8$ in 1851 , and the net cost from $£ 12.7 .3$ in 1851 to $£ 18.9 .1$ in 1855.
} 
As the Scottish penal system in the 1840s shifted towards a more stringent regime, Frederic Hill's influence over policy making waned as his personal style alienated his superiors. Although Hill was extremely hard working and dedicated, soon after the formation of the Board in 1840, Melville wanted Hill replaced by an inspector with more "tact and solidity." While admitting that Hill was energetic and knowledgeable, Melville disliked that he played "the man of importance" and considered him to be "incompetent from his want of tact and sober judgement to regulate his conduct." Melville was obviously nervous that Hill's behavior might jeopardize the plan to reform Scottish prisons. Melville, it appeared, did not think Hill to be the man to offer advice to sensitive magistrates and to provide general guidance to the public about the provisions of the Prison Bill.

Many of Hill's superiors also complained that he was too eager to fill his reports with comments that went beyond penal administration and discipline. The secretary of the General Board was furious with him when he offended the County Boards by his outspoken disappointment with the failure to establish a central authority over all the jails in the country. The Board publicly dissociated itself from the inspector's report and refused to cooperate with the Home Office, which urged its distribution. ${ }^{75}$ The Home Office also disapproved of Hill's reports, warning him repeatedly throuhout his tenure as Scottish inspector to restrict his comments to prison discipline in his annual reports. Hill refused to heed this firm warning and, in 1849, was again reprimanded for reports that embraced matters concerning the constabulary and the law of partnership which should have been communicated privately to the Secretary of State. ${ }^{76}$ Hill further antagonized Graham, with whom he had already disagreed over the direction of penal policy, when he pestered the Home Office to no avail in support of his right as an inspector to examine prisoners in private when visiting jails. ${ }^{77}$

Hill antagonized the General Board even more thoroughly when, on his own authority, he made recommendations to the County Boards, interfer-

\footnotetext{
'4Melville to Fox Maule, 30 January 1840, NLS, 354A/128. Melville commented, "In England or Ireland where the county magistrates have always been accustomed to the management of gaols, Mr. Hill could do little or no harm, because they would be quite as well able to judge as he could of the prospects of adopting any of his suggestions." Ibid. See also Melville to Fox Maule, LS, 354A/134.

${ }^{75}$ Murray to Melville, 6 August 1840, to Fox Maule, 19 August and 16 September; to Newell Burnett, 11 November 1840 , SRO, HH/7/1.

${ }^{76}$ Hill to Graham, 15 May 1846, PRO, HO 21/10; Manners Sutton to Hill, 10 May 1846, PRO, HO 21/10 and Grey to the Inspectors of Prisons, 25 May 1849, PRO, HO 45, OS 2581.

"Phillips to the Visiting Magistrates of Morpeth Jail, 6 November 1845; to Hill, 30 April 1846, Hill to Graham, 30 July, 28 October 1845, 3 April, 11 March 1846, PRO, HO 45, OS 1067.
} 
red with appointments, and demanded monthly reports, without consulting the Directors. The Home Office agreed his actions were "likely to weaken the authority of the Board, produce confusion, and to engender ill feeling between the General and County Boards," "78 and Graham acidly reprimanded the inspector for not confining himself "within the strict limit of [his] official duties." "19 Hill was ordered to communicate any suggestions to the General Board, but he was still free to communicate any "crying evil, which requires an immediate remedy" which might involve individual hardship or suffering, to the County Boards directly. ${ }^{80}$ As Hill had been warned in 1840 to issue only general and brief instructions to the counties, his insubordination was undeniable.

\section{IV}

Although plans to establish district prisons free from local control failed, the Board of Directors was given complete authority over the General Prison at Perth. After 1842, Perth incarcerated a growing number of those prisoners serving longer sentences. The expense for building Perth was met initially by a treasury grant of $£ 10,000$ and by $£ 26,500$ raised from assessments supervised by the Directors in the 1840s and 1850s. A further $£ 67,750$ in 1861 was granted by parliament to pay for additional wings and renovations. ${ }^{81}$ The counties in 1839 were assessed to pay the operating costs at Perth, but in 1846 the Treasury assumed the responsibility. The intention of the Prisons Act of 1839 was to send any prisoner sentenced to longer than six months to Perth. Although the intent was not met by 1853 , all male prisoners serving terms over nine months were accomodated by removing female prisoners to make room for the male transportees. But, beginning in 1855 , all male convicts were sent immediately after sentencing to convict and public works prisons in England and only females serving penal servitude and transportation sentences were housed at Perth. ${ }^{82}$ Scottish

\footnotetext{
"Graham to Melville, 10 January 1844, Graham Papers, Gen. S., B69A; Fox Maule to Hill, 29 October 1838, PRO, HO 21/8; Hill to Melville, 2 May 1840, NLS, 354A/149; Hill, Autobiography, p. 132; Hill to the Home Office, 7 March 1844, PRO, HO 45, OS 782.

"Graham to Hill, 14 February 1844, PRO, HO 45, OS 782. Graham stated "The General Prison Board of Scotland has been constituted specially for the purpose of overlooking, and of generally directing the Proceedings of the County Boards ...." Ibid; Hill to Graham, 7 March 1844, Ibid.

${ }^{\circ 0}$ Graham to Melville, 10 January 1844, Graham Papers, Gen. S., B69A.

"Twenty Second Report, PP, Vol. 29 (1861), pp. 536-7. $£ 2,000$ per annum was raised from assessments but this was lowered to $£ 1,200$ in 1854-this was paid off by 1858 .

${ }^{82}$ Twenty Second Report, PP, Vol. 29 (1861), p. 541. Local officials, reimbursed by the Treasury, were responsible for transporting the male convicts to England: e.g., in 1857, 118
} 
authorities disliked the removal of male convicts to England. Distant from their families and in an unfamiliar cultural setting, it was believed they were victimized by hard-core London criminals in the public works prisons. Eventually, in 1863, Scottish convicts spent the first stage of their punishment in Scotland. ${ }^{83}$

Perth was considered by the Directors to be a model prison for the rest of the country; it was here that separation to avoid "contaminating communication" was advertised as the "pure prison discipline." The Directors insisted on the success of the system for those sentenced to imprisonment, and only in the $1860 \mathrm{~s}$ was it admitted that separation did not prevent prisoners from being conscious of each other's presence. Masks worn during exercise and separate chapel stalls and partitioned exercise yards were removed so prisoners could identify one another, but they were still prevented from communicating. Separate stalls and closed exercise yards were only used as a "sedative" to punish misconduct. ${ }^{84}$

With the opening of the prison in the 1840 s to juveniles, criminal lunatics, and convicts serving long sentences, it appeared that the indiscriminate adoption of separation was no longer feasible. Young prisoners, psychologically and physically damaged by separation, took their prayers and instruction in association. ${ }^{85}$ This department shrank with the appearance of reformatory schools in the 1850 s and was finally discontinued in 1860. After 1846 Perth began to receive criminal lunatics from all over Scotland, and the Directors and Managers gained more power to remove them from local jails in 1857. Prisoners who became insane in jail, at the time of the trial, or when the criminal act was committed, could be sent to Perth at the discretion of the Directors rather than the courts. ${ }^{86}$ The

penal servitude convicts were sent to wakefield and 87 to Millbank. In 1852108 out of the 170 transportation convicts were removed from Scotland, Fourteenth Report, PP, Vol. 53 (1852-53), p. 435; Nineteenth Report, PP, Vol. 30 (1857-58), p. 544. After a number of escapes en route a special railway carriage was constructed with 18 cells for economy and security-two prisoners hacked through the roof in 1864 in order to escape. Twentieth Report, $P P$, Vol. 11 (1859), p. 283; Twenty First Report, PP, Vol. 34 (1860), p. 6; twenty Sixth Report, PP, Vol. 23 (1865), p. 477.

${ }^{83}$ Twenty Fourth Report, PP, Vol. 24 (1863), p. 494; Twenty Fifth Report, PP, Vol. 27 (1864), pp. 561, 567.

"Ibid., p. 538; Twenty Fifth Report, Managers of Scottish Prisons, Vol. 27 (1864), p. 560; Thirtieth Report, Vol. 29 (1868-69), p. 808.

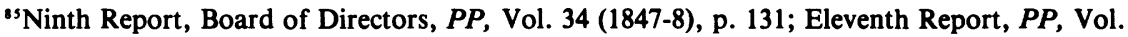
39 (1850), p. 441; Thirteenth Report, Inspector of Scottish Prisons, PP, Vol. 26 (1847-8), p. 514; Sixteenth Report, PP, Vol. 27 (1851), p. 843; see also Kincaid to grey, 23 October 1847, and Grey's reply, 3 November 1847.

${ }^{16}$ In 1862 the Managers, acting for the Secretary of State, could send any insane prisoner to Perth or even hold an insane inmate after the expiration of his or her sentence. Twentieth 
separate system was relaxed for a number of these inmates, and the penal character of the institution receded when the National Establishment for Criminal Lunatics was founded in 1864 on the site of the juvenile prison. The department, supervised by medical personnel, treated inmates from an "alleviative and curative" standpoint. ${ }^{87}$

The separate system also had to be modified to meet the needs of prisoners sentenced to penal servitude as an alternative to transportation. The system was relaxed for those convicts as the Directors felt long periods of separate confinement would be detrimental to the prisoners' health. After a year in separate confinement, convicts were allowed to work in association in the laundry and wash house built in the 1850s. Discipline was relaxed by stages, and after 1855 the convicts, all of whom were women, were permitted to wear shorter gowns, to receive more visitors, and to have reading materials and letters. After the 1857 Penal Servitude Act, which finally abolished the sentence of transportation, a more elaborate stages system was developed as the convicts qualified for remission based on their conduct. Officers made a "minute daily record of conduct and industry" to evaluate the progress of the prisoners which, in turn, helped to maintain good order in the prison. ${ }^{88}$

The responsibility for maintaining female convict prisoners in Scotland taxed the resources of the system in the 1850s. Despite the expansion of Perth from 360 to almost 900 separate cells, the large number of female convicts placed in the general prison led to overcrowding and poor discipline. The government, as a temporary solution, rented eighty-three cells at Ayr prison, which was not well managed and was plagued with disciplinary problems and suicides. At Perth convicts voiced a series of complaints about the lax discipline in the female wing, and in 1856 the Board dismissed the matron for not enforcing the rules. Convicts who became "irritated and discontented" when their sentences, in their opinion, were not remitted fairly, confronted the authorities. This anxiety came to a head in 1862 when troops were called in to quell a serious disturbance. The inmates, holding skeleton keys, had gained considerable control over the prison, escaping observation amidst the older structures on the grounds. In

Report, PP, Vol. 11 (Sess. 1) (1859), p. 560; Thirtieth Report, Managers of Scottish Prisons, Vol. 29 (1868-69), p. 808.

${ }^{87}$ Eighteenth Report, Board of Directors, PP, Vol. 7 (1857), p. 589; Twentieth Report, PP, Vol. 11 (Sess. 1) (1859), p. 284; Twenty Second Report, PP, Vol. 29 (1861), p. 531; Twenty Fourth Report, Managers of Scottish Prisons, PP, Vol. 24 (1863), p. 413; Twenty Fifth Report, PP, Vol. 27 (1864), p. 559; Twenty Sixth Report, PP, Vol. 23 (1865?, p. 474.

${ }^{83}$ Twenty Third Report, PP, Vol. 25 (1862), p. 250. 
response, a system was introduced in 1864 by which obedient female convicts could gain marks towards remission by working hard. Marks could equally be removed to discourage a poorly disciplined minority from idly awaiting their release. ${ }^{89}$

The early exposure of shocking conditions in Scottish prisons led to the adoption of a measure of centralized administration in Scotland some twenty-five years before similar measures were adopted in England. The General Board of Directors was empowered to supervise assessments for building prisons, to close unsuitable establishments, and to determine precisely what categories of prisoners should be legally housed in local jails. Although plans to bring all Scottish prisons under central supervision failed, the General Board dominated the partnership with the County Boards, which managed the local jails on a day-to-day basis. The Directors could dismiss prison personnel and frame rules that the County Boards adopted in the localities. In England, where this administrative relationship did not exist, new prison rules had to be passed by individual Acts of Parliament and the Home Office could only provide guidelines for action. Hill, when he became the inspector for northern England in the late 1840s, praised the Scottish system as "more simple and energetic," because the presence of County Boards eliminated the distinctions between the counties, boroughs, magistrates, and town councils which still existed in England. Since the County Boards included representatives from the burghs, there was no possibility they could veto measures as did the borough magistrates in England. Moreover, the existence of the County Boards destroyed the division of authority between the County bench and the visiting justices which in England often led to a great deal of delay both in the appointment and dismissal of governors and in the promulgation of new rules for local jails. Hill remarked that the County Board's superiority was "shown by the comparative promptness with which suggested improvements are considered and decided upon, and with which ill-qualified officers are removed." Hill was also impressed that the County Boards were allowed to select persons to sit on the Board who had some special knowledge of penal discipline, rather

\footnotetext{
"Nineteenth Report, Board of Directors, PP, Vol. 30 (1857-8), p. 548; Twenty First Report, $P P$, Vol. 36 (1860), p. 7; Twenty Fourth Report, Managers of scottish Prisons, PP, Vol. 24 (1863), pp. 412-13; Twenty Sixth Report, PP, Vol. 23 (1865), p. 472; Twenty Eighth Report, $P P$, Vol. 25 (1867), p. 585; Twenty Ninth Report, $P P$, Vol. 25 (1867-68), p. 785; Thirtieth Report, $P P$, Vol. 29 (1868-69), p. 810.
} 
than having to rely solely on inexperienced landowners or members of town councils. ${ }^{90}$

Under the administrative structure established in 1839 there is considerable evidence that uniform standards were established in jails throughout Scotland by 1860 . An extensive building program based on the separate system was considered virtually complete by the time the supervision of prisons passed from the Directors to the Managers of Scottish prisons who were even more closely responsible to the Secretary of State.

This situation contrasted sharply with the conditions that prevailed in local prisons in England where separation had been far from universally adopted. The Canarvon Committee in 1863 urged the Home Office to assume greater power to force a uniform system of separation on the visiting magistrates after they heard evidence of overcrowding, poor discipline, and the lack of standardization of punishment in the various local prisons in England. ${ }^{91}$ Evidence of the progress made in Scotland was reflected by the fact that the Prisons Act of 1865 , which attempted to enforce adherence to the Separate System by the withdrawal of a grant in aid from the Home Office, did not include Scotland. ${ }^{92}$ The County Boards, however, were abolished in 1877 when both Scottish and English prisons were completely centralized.

With the introduction of the Prisons Bill in 1839 there was some reason to believe that Scottish prisoners would be subjected to a regime that differed from that in England. Closer central supervision over conditions and facilities provided Scottish prisoners with healthier physical conditions than those experienced by their counterparts in England. In addition, there was an attempt to provide a modicum of education and instruction in productive labor in Scottish prisons administered by more carefully selected personnel who were not allowed to resort to flogging their charges. The infusion of English expertise and direction over Scottish penal policy was considerable throughout the period. Frederic Hill, drawing from the humanitarian background of Elizabeth Fry and utilitarian assumptions of Bentham, strongly influenced policy in the late 1830 s and early 1840 s which stressed productive labor and secular and religious education. ${ }^{93}$ Without de-

${ }^{90} \mathrm{Hill}$, Crime, pp. 339, 379-80; Thirteenth Report, Inspector of Prisons (Northern District), p. 399.

9'McConville, "English Prison Administration," pp. 365-378, PP, Vol. 12 (1863), pp. i-xiv, 253.

${ }^{92}$ Hansard, Vol. 177, pp. 215-218; two Home Office circulars to local justices, 9 December 1865 and 23 March 1866, HO 22/14.

${ }^{93}$ For a full discussion of the ideas of penal reform in the 1830 s and 1840 s see Robert Alan Cooper, "Bentham, Fry and English Penal Reform," Journal of the History of Ideas 42, No. 4 (1981):675-90. 
nying the relatively humane intentions of his ideas, Hill clearly saw that the function of the penitentiary was to both liberate and control the prisoner. $\mathrm{He}$ intended that Scottish prisoners be more strictly disciplined than in many prisons in the south. Hill hoped that in this atmosphere, prisoners would be trained and convinced of the values of a free market economy that would liberate them from dependency and promote social harmony. If prisoners were treated benevolently in a well-ordered, and even cheerful environment, Hill argued, they would become capable of rational selfimprovement and he believed even criminals if exposed to education had the ability for self-development and independence. ${ }^{94}$

At no time, however, was penal philosophy or policy left exclusively in the hands of Hill. In the 1840s, the Directors were influenced by Jebb and Crawford, backed by Graham at the Home Office, who urged the implementation of policies that were being obstructed in the south by obstinate parsimonious local magistrates. The Scottish system, which in the late $1840 \mathrm{~s}$ and $1850 \mathrm{~s}$ shifted towards stricter deterrence, failed to develop an independent approach to penal reform and emphasized the features that officials hoped would be adopted in the interest of promoting national uniformity. Jebb and Crawford disturbed by the less stringent aspects of the Scottish Prisons Bill advocated, as we have seen, the adoption of the separate system and stressed its punitive and deterrent aspects to break and bend short-term prisoners. Moreover, the English officials, with the strong support of Kincaid, who replaced Hill in 1849 as inspector, rejected the beneficial and moral effects of productive labor and endorsed hard labor in a move to make prisons less eligible than the conditions experienced by paupers and free laborers. These ideas were in keeping with the sense of disillusionment with idealistic and purely reformist ideas of penal discipline shared in both countries. The uniform imposition of penal labor was never a total success on either side of the border as local authorities clung to productive labor for financial reasons. Nevertheless, the tread wheel and crank were instituted in 1849, while their official adoption in England waited until 1865. The influence of the English convict service was particularly evident at Perth where the modifican of the separate system closely paralleled developments in England. With the demise of transportation, an elaborate

${ }^{94} \mathrm{Hill}$ presented his ideas of prison reform in his long reports as an inspector in Scotland and Northern England. See Second Report Inspector of Scottish Prisons, PP, Vol. 22 (1857), pp. 773-7; Third Report, PP, Vol. 21 (1837-8), pp. 3-10, Fourth Report, PP, Vol. 22 (1839), p. 471; Fifth Report, PP, Vol. 26 (1840), pp. 5-6; Seventh Report, PP, Vol. 21 (1842), pp. 374-381, Eighth Report, PP, Vol. 22 (1843), pp. 448-9; Tenth Report, PP, Vol. 24 (1845), pp. 403-13; Eleventh Report, PP, Vol. 20 (1846), pp. 471-82; Twelfth Report, PP, Vol. 29 (1847), pp. 386-98. 


\section{Albion}

system of punishment in stages was developed to accommodate prisoners sentenced to penal servitude. ${ }^{95}$ However, Perth was not merely a government prison that housed transportation and penal servitude convicts; all persons sentenced to long periods of imprisonment in Scotland were sent to the national prison.

The unique administrative structure that involved greater centralization brought mixed blessings for the Scottish prisoner. In the 1850s they were subjected to a stricter regime than many prisoners in the south who felt the effects of this harsher attitude only after 1865 when local jails in England fell more directly under the Home Office.

${ }^{95}$ For a full discussion of the Convict Service see M. Heather Tomlinson, "Penal Servitude 1846-1865: A System in Evolution," in Bailey, Policing and Punishment, pp. 126-149; David Smith, "The Demise of Transportation: Mid-Victorian Penal Policy," Criminal Justice History 3 (1983):15-32; McConville, "English Prison Administration," pp. 177-87. 